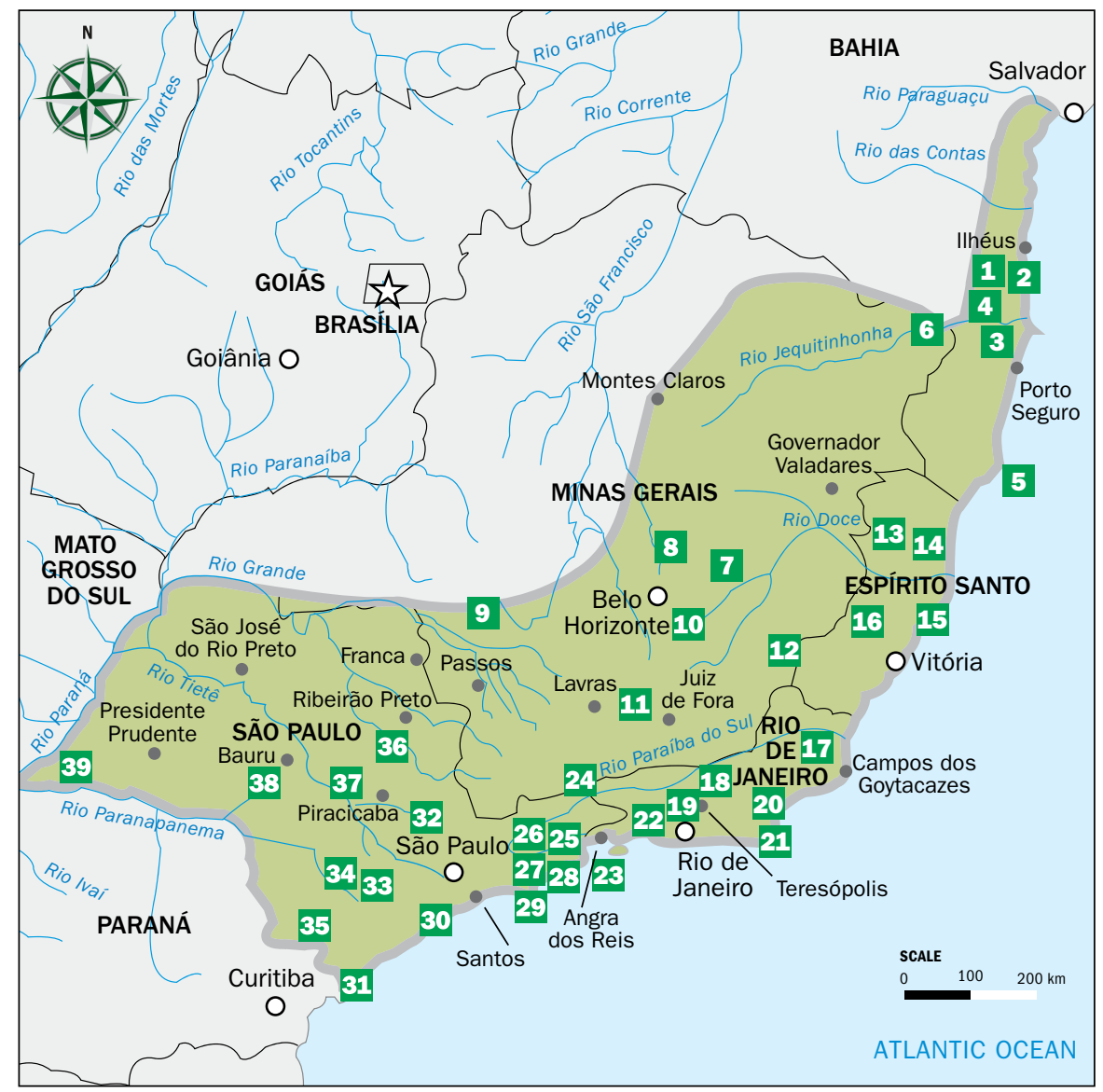

\title{
Parks and Places
}

Some notable places for bird finding.

Prior authorization for visits may be necessary.

1 PN Serra das Lontras

2 Reserva Biológica Una

3 RPPN Estação Veracel

4 Serra Bonita

5 PN Marinho Abrolhos

6 RPPN Mata do Passarinho

7 PE Rio Doce

8 PN Serra do Cipó

9 PN Serra da Canastra

10 RPPN Santuário do Caraça

11 PE Ibitipoca

12 PN Caparaó

13 Reserva Biológica de Sooretama

14 Reserva Natural Vale
15 Reserva Biológica de Comboios

16 Reserva Biológica Augusto Ruschi

17 PE do Desengano

18 Serra dos Órgãos

19 REGUA (Reserva Ecológica de Guapiaçu)

20 Reserva Biológica União

21 Cabo Frio

22 PN Tijuca

23 Ilha Grande

24 PN Itatiaia

25 PN Serra da Bocaina

26 Campos do Jordão

27 São Luiz do Paraitinga
28 Ubatuba and Paraty

29 Ilhabela

30 Estação Ecológica Jureia-Itatins

31 Ilha do Cardoso

32 Serra do Japi

33 PE Carlos Botelho

34 PE Intervales

35 Petar (Parque Estadual Turístico Alto Ribeira)

36 Itirapina

37 Fazenda Bacury and Tanquã

38 Estação Ecológica de Caetetus

39 PE Morro do Diabo

PN: National park | PE: State park | RPPN: Private Natural Heritage Reserve 
Protecting Wild Brazil Chapter

\section{Text Authors}

Martha Argel (wCS)

Tim Hirsch

John A. Gwynne (WCS)

\section{Photographers}

Ciro Albano

Theo Anderson

Boeri Studio

Demis Bucci

Fabio Colombini

Valdemir Cunha

Carolina Da Riva

Pavel Dodonov

Lilian Sayuri Fitorra

\section{Advisory Committee}

Martha Argel (WCS)

Juan Mazar Barnett

(In Memoriam, 1975-2012)

Dennis Driesmans Beyer

(Animalia Consultoria em

Meio Ambiente)

Dante R. C. Buzzetti

Braulio Carlos

(Pantanal Bird Club)

Pedro F. Develey

(SAVE Brasil/BirdLife)

Neiva Guedes (Projeto Arara Azul)

John A. Gwynne (WCS)
Bruno Lima

Silvia Faustino Linhares

Luiz Claudio Marigo

(In Memoriam, 1950-2014)

Dimitri Matoszko

Fabio Olmos

Haroldo Palo Jr.

Júnior Petar

Ernesto Reghran/

PULSAR Imagens

Alexine Keuroghlian (WCS)

Katherine Lemcke (WCS)

Vincent Kurt Lo (IBAMA)

André De Luca

(SAVE Brasil/BirdLife)

Fernanda Marques (wCS)

Fernanda Melo

(Caiman Ecological Refuge)

Leonardo Vianna Mohr

(ICMBio - Ministério do Meio Ambiente)

Vitor Piacentini

(Museu de Zoologia da USP)
Luciano Lima
André Saidenberg

José Robson dos Santos

Mucio Scorzelli

Guilherme Serpa

Robson Silva e Silva

Lindolfo Souto

Thiago Tolêdo

Flávio Varricchio

Wallace Wittkoff

Maria Antonietta Pivatto

(Photo In Natura)

Wandir Ribeiro

(Jatobá Engenharia Florestal)

Rômulo Ribon

(Universidade Federal de Ouro Preto)

Robert S. Ridgely

(Rainforest Trust)

Fernando C. Straube

(Hori Consultoria Ambiental)

Eduardo Martins Venticinque (WCS)

Carlos Yamashita (IBAMA)

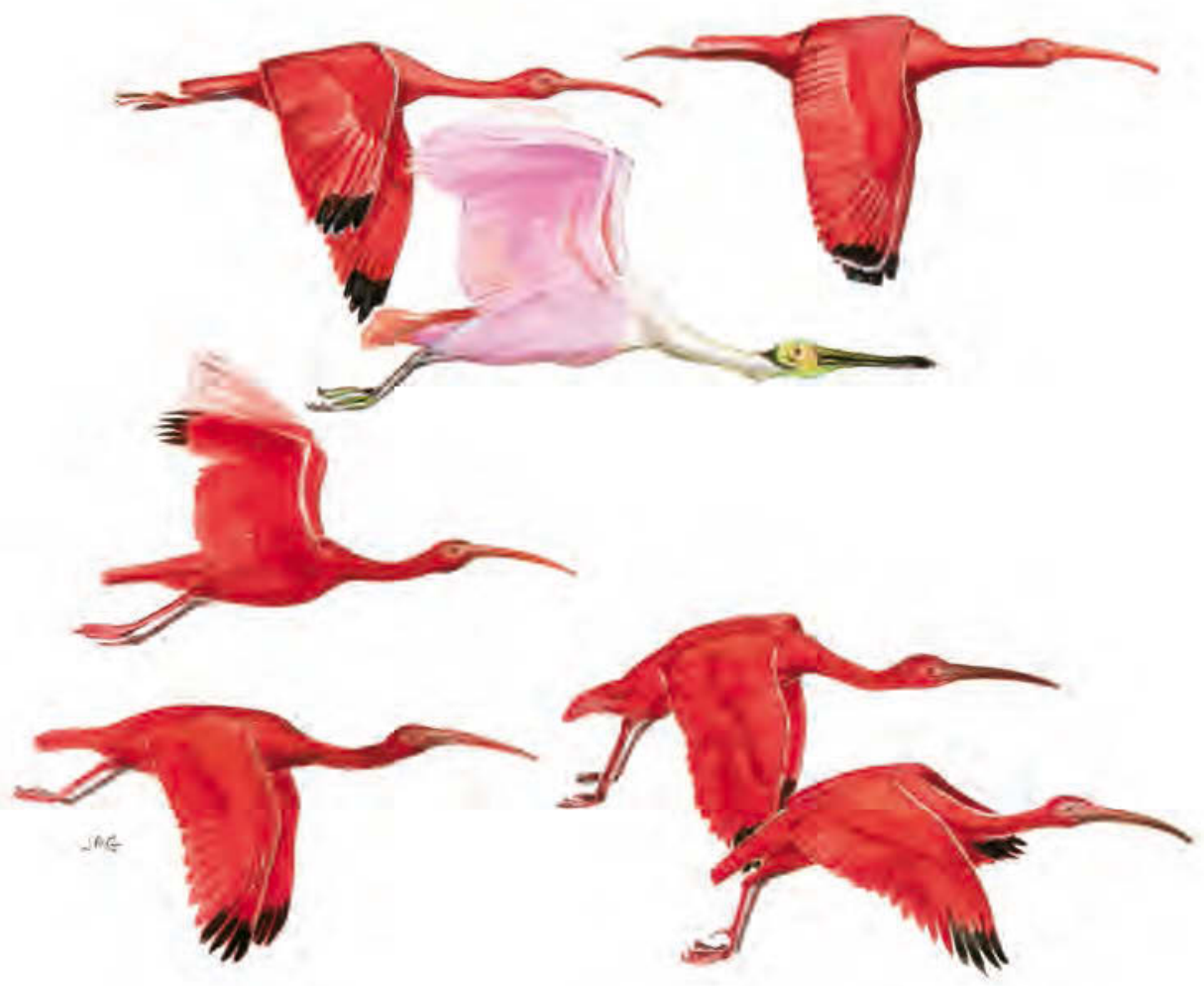




\section{WILDLIFE CONSERVATION SOCIETY BIRDS OF BRAZIL \\ THE ATLANTIC FOREST \\ OF SOUTHEAST BRAZIL}

INCLUDING SÃO PAULO \& RIO DE JANEIRO

Senior Author: Robert S. Ridgely

WCS Project Director: John A. Gwynne

Art Director: Guy Tudor

WCS Project Coordinator

and Translator: Martha Argel

Book Design and Production: Terry Clarke

Artists:

Guy Tudor

Michael DiGiorgio

Dale Dyer

John A. Gwynne

Barry Van Dusen

Sophie Webb

Species Maps: Robert S. Ridgely,

Maria Allen, and Terry Clarke

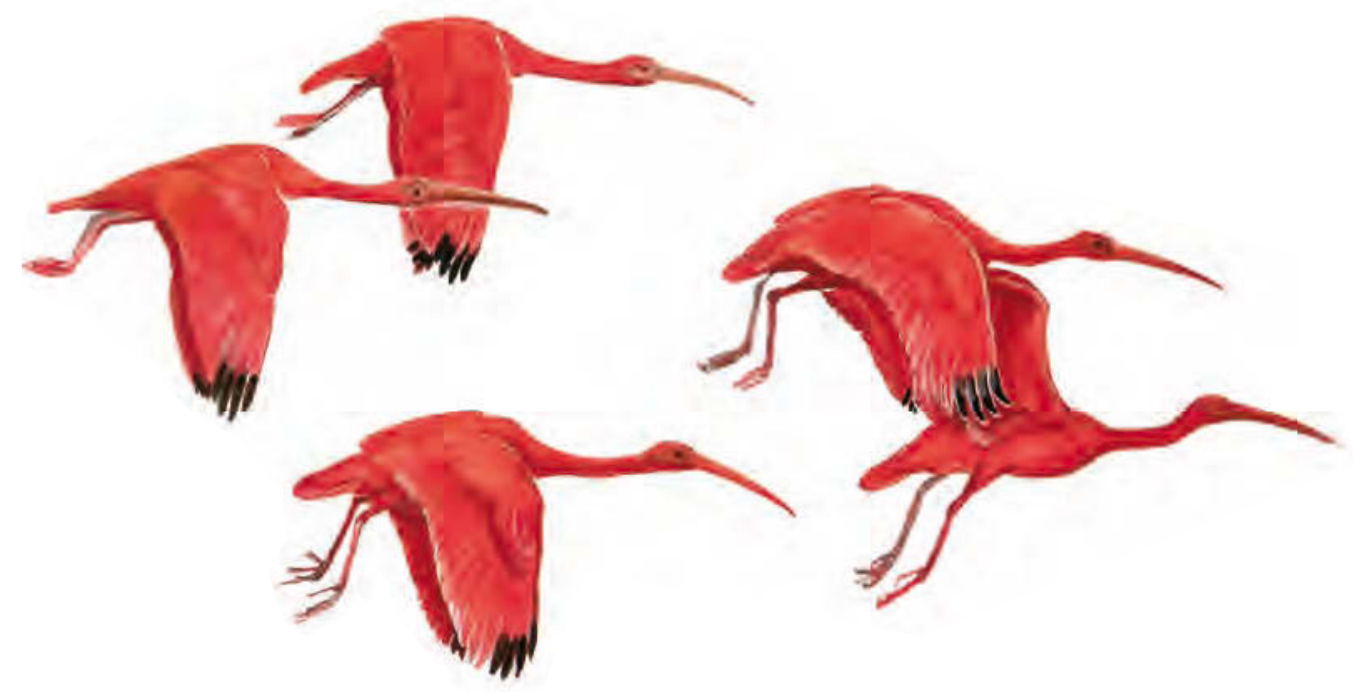

Comstock Publishing Associates

a division of Cornell University Press

Ithaca and London 


\section{Copyright ( 2016 by Wildlife Conservation Society}

Species accounts and associated maps on pages 32-400 copyright (c) 2016 by Robert S. Ridgely

(Recommended citation: Ridgely, Robert S., John A. Gwynne, Guy Tudor, and Martha Argel. Wildlife Conservation Society Birds of Brazil: The Atlantic Forest of Southeast Brazil, including São Paulo and Rio de Janeiro. Ithaca: Cornell University Press, 2016. Ridgely. Species Accounts.)

Illustrations by Guy Tudor from The Birds of South America, Volume 1: The Oscine Passerines, copyright (C) 1989; The Birds of South America, Volume 2: The Suboscine Passerines, copyright (c) 1994; and Field Guide to South American Songbirds, copyright (c) 2009, by Robert S. Ridgely and Guy Tudor. Used by permission of the illustrator and the University of Texas Press.

All rights reserved. Except for brief quotations in a review, this book, or parts thereof, must not be reproduced in any form without permission in writing from the publisher. For information, address Cornell University Press, Sage House, 512 East State Street, Ithaca, New York 14850.

First published 2016 by Cornell University Press

First printing, Cornell Paperbacks, 2016

Printed in the United States of America

\section{Library of Congress Cataloging-in-Publication Data}

Wildlife Conservation Society birds of Brazil /

WCS project director, John A. Gwynne; senior author, Robert S. Ridgely.

v. $\mathrm{cm}$.

Includes bibliographical references and index.

Contents: v. 1. The Pantanal and Cerrado of Central Brazil

ISBN 978-0-8014-7646-4 (v. 1 : pbk. : alk. paper)

ISBN 978-1-5017-0453-6 (v. 2 : pbk. : alk. paper)

1. Birds--Brazil--Identification. I. Gwynne, John A. II. Ridgely, Robert S., 1946- III. Wildlife Conservation Society (New York, N.Y.) IV.

Title: Birds of Brazil.

QL689.B8W53 2010

598.0981--dc22

\section{8}

Cornell University Press strives to use environmentally responsible suppliers and materials to the fullest extent possible in the publishing of its books. Such materials include vegetable-based, low-VOC inks and acid-free papers that are recycled, totally chlorine-free, or partly composed of nonwood fibers. For further information, visit our website at www. cornellpress.cornell.edu.

Paperback printing 10987654321 


\section{Projeto Aves do Brasil}

gratefully acknowledges the vision and generosity of donors who have made this project possible:

Sam and Nora Wolcott

Fundação Grupo Boticário

Fibria

Votorantim

Abigail Congdon and Joe Azrack

Polly Bruckmann

Edith McBean

Graham Arader

Muriel Matalon

The Penates Foundation

Adeline and Ted Kurz

Dane Nichols

Anonymous Donors 


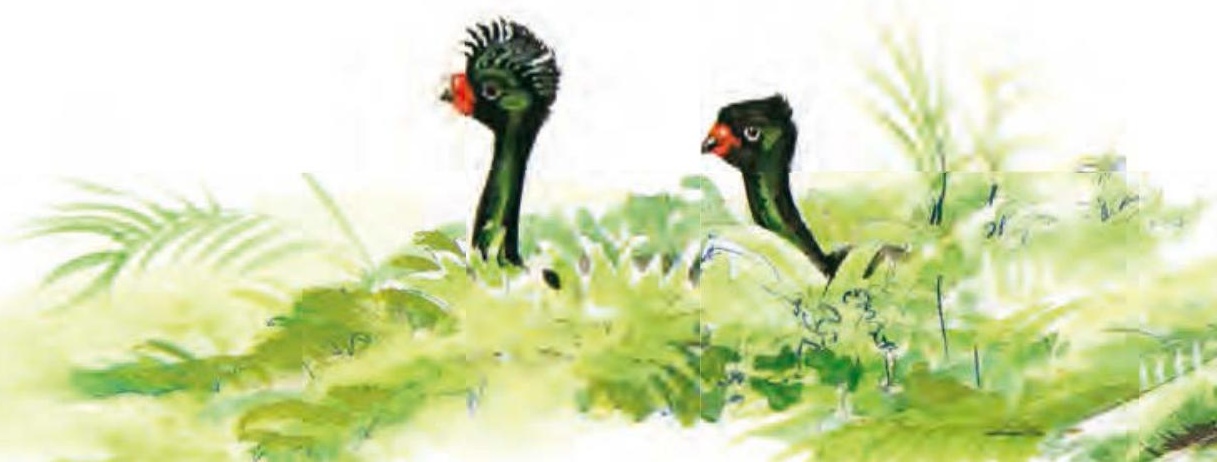


The Wildlife Conservation Society gratefully dedicates this volume to Sam and Nora Wolcott.

Their unwavering support of Projeto Aves do Brasil has enabled the world to better understand and appreciate the wonders of Brazil's birds. 


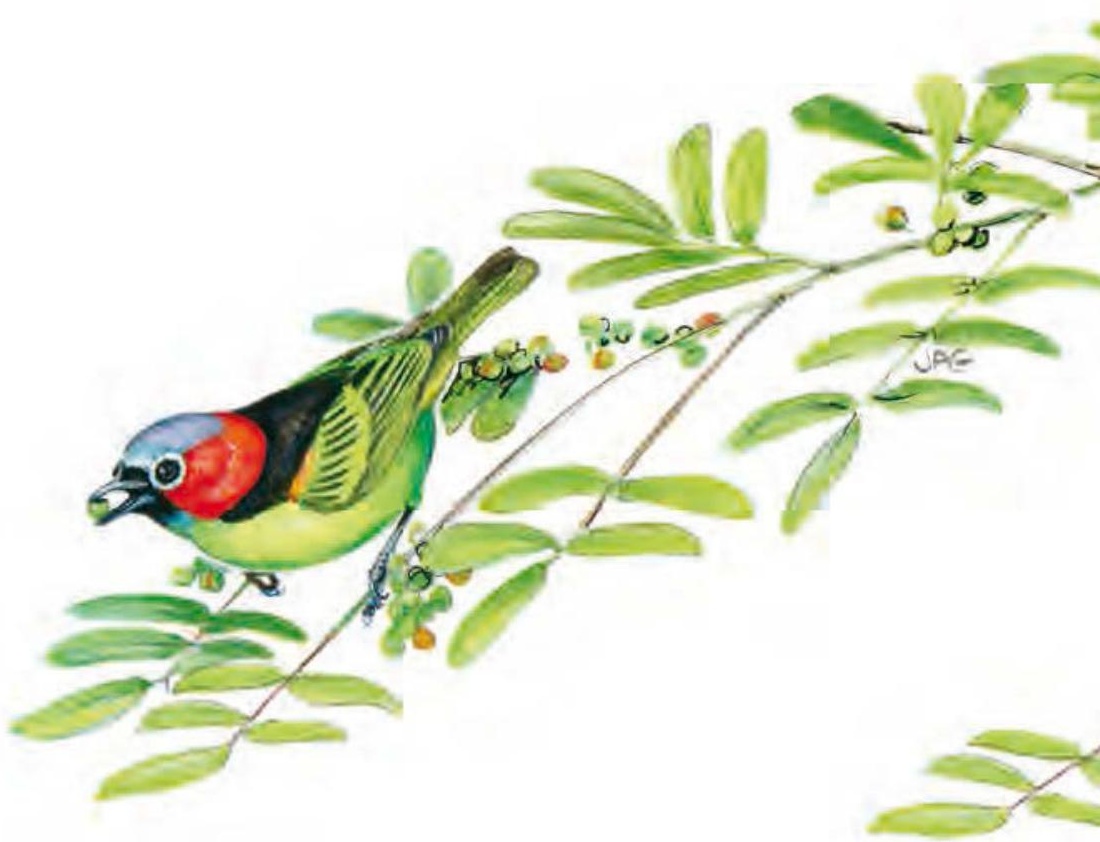

